\title{
A Hijab, A Dog, and Many Histories: Wonders of Intersectional Assemblage in Memphis
}

\author{
Wesam M. Salem, Leslee Bailey-Tarbett, and Susan Naomi Nordstrom
}

University of Memphis, Memphis, United States of America

\begin{abstract}
As part of a larger interdisciplinary arts-based research course, we engaged in walking as a material and relational inquiry in order to disrupt privileged and normalized understandings of class, race, settler colonization, and narratives of othering (Springgay \& Truman, 2018). Borrowing Jasbir Puar's (2012) frictional analysis, that brings together intersectionality (Crenshaw, 1991) with Deleuze and Guattari's (1987) assemblage, each of the walks sought to "foreground the mutually co-constitutive forces of race, class, sex, gender, and nation" (Puar, 2012, p. 49). As we walked Memphis' historic neighborhoods, we experienced varying states of wonder as intersecting identities shifted with each step in and out of centers and margins or what Min-Ha (1991) terms as "horizontal vertigos" (p. 15). In this paper, we share two of our "horizontal vertigos" that shaped our experiences walking Memphis neighborhoods and that informed our understandings of the frictional movements in the assemblage and the event-ness of identities.
\end{abstract}

\section{Keywords}

Postcolonialism; posthumanism; intersectionality; arts-based research 


\section{Introduction}

As part of a larger interdisciplinary arts-based research course, we engaged in walking as a material and relational inquiry in order to disrupt privileged and normalized understandings of class, race, settler colonization, and narratives of othering (Springgay \& Truman, 2018). The class structure displaced traditional notions of teaching and learning by opening up pedagogical spaces to new opportunities for thinking about being and learning in public spaces. The course activities (e.g. blogging, walking, and arts-based research and representation) resided in both traditional classrooms and public spaces where we (both students and instructors) 'walked-with' Memphis neighborhoods (Springgay \& Truman, 2018). Moving outside the confinement of the physical classroom into public spaces allowed bodies to wander with and within the space, time, and matter of the neighborhoods. By blurring boundaries and crossing limits, we displaced where and how teaching and learning materialized.

We walked two neighborhoods in the urban city of Memphis, Tennessee (United States) individually and in small groups during the semester, and we blogged about each of our walks. Because of the diversity of disciplines represented in the class (e.g., education, anthropology, communication, and art), students walked with their own unique set of experiences, disciplinary practices, positionalities, theoretical orientations, understandings of Memphis history, and so on. ${ }^{i}$ Borrowing Jasbir Puar's (2012) frictional analysis, that brings together intersectionality (Crenshaw, 1991) with Deleuze and Guattari's (1987) assemblage, each of the walks sought to "foreground the mutually co-constitutive forces of race, class, sex, gender, and nation" (Puar, 2012, p. 49). ${ }^{\text {ii }}$ The first walk attended to our bodies, movement and senses and how they unfolded with the neighborhoods. The second walk examined intersections, boundaries and openings. Then, we attended to one of the four practices of walking articulated by Jacks (2004)—sighting, measuring, reading, and merging_during the third walk. For example, the third walk encompassed gazing and making visual connections with the spaces, surveying Google Maps occasionally to identify location, and reading about the history of the place while maintaining awareness of the time. It was within the fourth walk that we examined our past walks and created our own propositions to further examine intersectionality in Memphis. Intersectionality, in Puar's (2012) words, was "supplemented-if not complicated and reconceptualized—by a notion of assemblage" (p. 50). Intersectionality was further informed by the culmination of our thinking about the previous three walks, theories read in the course (e.g. Manning, 2016; Puar, 2012; Haraway, 2016), and the blogs written after each walk. The entanglement of humans and non-humans and their dynamic movement between the assemblage of bodies, signs, and matter shaped and informed our experiences. Therefore, assemblages center "variation to variation" dismissing a constant positioning of the subject; thus, the event-ness of identity (Deleuze and Guattari, 1987).

As we studied the blogs, we began to see how everyone experienced varying states of wonder as intersecting identities shifted with each step in and out of centers and margins or what Min-Ha (1991) termed as "horizontal vertigos" (p. 15). In this paper, we share two of our "horizontal vertigos" of the to and fro-movement from the margin that shaped our experiences of walking Memphis neighborhoods, and informed our understandings of the frictional movements in the assemblage. While institutional uptakes of intersectionality can reify subject positionalities into categories of race, gender, religion, etc., assemblages work frictionally to de-center the bodily matter so it is not de-segregated into static identity formation (Puar, 2012). 


\section{A Hijab}

For me, Wesam, a Jordanian American female, who immigrated to the USA with her husband and children 19 years ago, the walks were associated with "the pain and the frustration of having to live a difference that has no name and too many names already" (Minh-Ha, 1991, p. 14). As a practicing Muslim who wears the headscarf or the hijab, walking brought my visible Muslim identity to the fore. The hijab, that piece of cloth I wear on my head, becomes a mark on the body that materializes difference and "radically striate[s]" the margin (Minh-Ha, 1991, p. 14), so much so that sometimes it felt as though the scarf took the walk, not me.

One fall afternoon, the white silk scarf walked the Annesdale neighborhood in Memphis for the first time. Stepping over brown and red leaves, passing by historic houses and trails, and feeling the chilly air, the scarf felt joy and relief as the space appeared kind and welcoming. Talking to itself, the headscarf wondered why it had not walked this space before. Alongside this joy and contentment and not knowingly, the walking scarf stirred the stillness and the norm of the space, invoking difference. The 'not from here' appearance of the scarf compels an African-American male resident, working on his lawn, to approach it. The scarf noticed his face, which asked "Who are you? What are you? Why are you here?" without the need to speak these thoughts. The joy and contentment came to a screeching halt initiating a horizontal vertigo leaving the center to be placed in the margin. The scarf immediately comprehended the signal, comprehended the need to show its 'identity papers.' The man approached "Do you speak English?" Headscarf replied, "I do!" Being used to feeling estranged, the scarf added that it is a student at the University of Memphis; furnishing further identity papers. The scarf is speaking English, the language of its master, and appeared to be in compliance with the Western regimes of truth, being a student at the university. Feeling at ease, the man smiled and wondered if the headscarf is looking for a rental property considering the neighborhood being adjacent to the University of Memphis. "Not really!" the headscarf replied. "I am just walking the neighborhood."

Stepping out of the car to adopt an on-feet perspective of the neighborhood invoked a sense of the 'Other:' The invisible became visible. When the scarf is positioned on the head to fully cover the hair as opposed to around the neck, it becomes a signal of difference and marginality. The salient rhetoric of Islamophobia, alongside the Orientalist representation of the hijab as a sign of oppression and backwardness, render Muslim girls and women as different and foreign (Zine, 2006). The headscarf strips the human body from its humanity to deem it disposable and foreign within the politics of belonging. The headscarf becomes a cloth of prejudice and intolerance. A Muslim, head-covering, Middle Eastern, an Arabicspeaking woman becomes an intensity of disturbance that seems outside the dominant colonial discourse of what and who is qualified to inhabit the space. The horizontal vertigo constituted by the scarf's identity papers or lack thereof remains in motion, processed and orchestrated by the dominant colonial discourses.

\section{Beyond Boundaries: A Dog and Many Histories}

For me, Leslee, a cis-white woman, taking an afternoon walk with my dog was unassuming. This was simply a repetition of accepted norms in the upper-middle class, predominantly white Memphis neighborhood of Central Gardens. Walking with Murray (my dog) down the widest, most prominent thoroughfare of the historic neighborhood, the ground beneath our feet became a map of scents, which determined if we slowed or lingered. This meant walking with the sidewalk, the grass, the trash cans at the curb, the curb, and so on. This sensory flood displaced habitual walking, offsetting typical patterns of thought and attention. 
Under the canopy of Southern Magnolias and English Oaks, I tried to be inside my bodythat-is, I tried to stay present and feel through my senses as well as notice how my body engaged relationally with the environment. I read the historical markers and I imagined what this street might have looked like in the early $20^{\text {th }}$-century, when the development began. According to the plaque, Central Gardens began as a home to Memphis' most prominent citizens. Though I tried to concentrate on how my body moved through the space, I was lost in thinking of the past. Who lived in this neighborhood? Who was excluded from living here? The echoes of the past traversed the present moment as I walked from home to home. The emerging of events, through time and space, made me question the history of a space deemed historic.

Physical boundaries of the neighborhood intensified the relations with and among the residents and brought to the fore questions of power, identity, race, gender, and socioeconomic status. Noticing the distinctive boundaries - the large plaques, stone pillars, and iron gates - generated questions about the neighborhood's historic status. The echoes of the past seeped into view, obscuring the picturesque landscape. A heaviness hung in the humid air. What histories have been hidden and differences erased in order to preserve this 'historic' white space?

In encountering this question, another walking partner materialized: archived Central Gardens Neighborhood Association newsletters (spanning over 50 years). Walking-with the text and images from the newsletters became an "activation device to mobilize thought, stimulate differentiation, and act as tensiles - capable of being stretched, but also in frictional tension” (Truman \& Springgay, 2018, p. 136). Reading, thinking and walking with the "normalized and sanitized" (Truman \& Springgay, 2018, p. 51) language of those letters culminated in a "historicization of the 'event' of intersectionality" (Puar, 2012, p. 53), which Puar argues is necessary in order to critique the shifting political and economic landscape of a particular context. The assemblage of objects, public space, time, and relations produced "an intensification of the body's relation to itself (one definition of affect)...the placements within the space have not necessarily altered, but the intensified relations have given new capacities to the entities" (Puar, 2012, p. 60-61). Walking with the newsletters generated complex understandings of the racist and classist discourses embedded in the quest for historic status. For example, in an excerpt from a 1988 newsletter, residents are urged to stay committed to strict zoning in order to keep their neighborhood free from "deterioration." The newsletter authors wrote,

Because Central Gardens is an "island" surrounded by commercial properties and deteriorating residential neighborhoods, strict enforcement of zoning within Central Gardens is absolutely essential if we are to remain a desirable residential neighborhood - one of the very few such neighborhoods "left inside the parkways." Central Gardens is in a precarious situation and is peculiarly susceptible to deterioration if we do not help one another enforce applicable zoning laws. To get an idea of what happens when variances to zoning are granted routinely and when people are allowed to violate zoning standards by the neighbors, we need to look no further than Annesdale/Rozelle neighborhood west of Cleveland, where strip apartments, nursing homes, boarding houses and halfway houses have led to the deterioration of a historic neighborhood of stately homes. Please help us prevent this from happening to Central Gardens (Central Gardens Neighborhood Association, 1988, p. 3).

The newsletters sought to silence and keep out what was deemed to be undesirable bodies, incompatible to live in this historic neighborhood. Walking-with the newsletters folded the present into a space soaked with history, power, and ghostly fear of the Other. It produced 
unpredicted lines of flight and challenged the notion of temporality and place. Walking-with this assemblage transcended linear time, as the present moment materialized the past and pointed to the future. It disrupted the association's 'activist' narrative that gaining historic status (i.e. protecting property values by enforcing zoning) preserved the neighborhood for future generations.

\section{Intersectionality in Memphis?}

The forces of colonial discourses of categories and binaries overshadowed the walks and orchestrated the horizontal vertigos that mapped difference into centers and margins (Puar, 2012). The same colonial discourses and practices rendered some bodies as 'belonging' to the center while 'othering' other bodies. Walking-with these public spaces assembled intersectional encounters of wonder that "def[ied] the world of compartmentalization and the systems of dependence it engenders" (Minh-Ha, 1991, p. 23) and disrupted our patterns of thinking and being. As Puar (2012) argues, "Categories—race, gender, sexuality, [and religion] - are considered events, actions, and encounters between bodies, rather than simply entities and attributes of subjects" (p. 56). We walked-with, became-with, and wonderedwith the sensations of horizontal vertigo as we moved to and fro in the assemblages in which we found ourselves.

\section{References}

Braidotti, R. (2012). Interview with Rosi Braidotti. In R. Dolphijn \& I. van der Tuin (Eds.), New materialism: Interviews \& Cartographies (pp. 19-37). Ann Arbor, MI: Open Humanities Press.

Central Gardens Neighborhood Association. (1988, April). Zoning. Central Gardens News. $1(3), 3$.

Crenshaw, K. (1991). Mapping the margins: Intersectionality, identity politics, and violence against women of color. Stanford Law Review, 43, 1241-1299.

Deleuze, G., \& Guattari, F. (1987). A thousand plateaus: Capitalism and schizophrenia (B. Massumi, Trans.). Minneapolis, MN: University of Minnesota Press.

Haraway, D. J. (2016). Staying with the trouble: Making kin in the Chthulucene. Durham, NC: Duke University Press.

Lauterbach, P. (2016, March). Memphis burning. Places Journal. https://doi.org/10.22269/160307

Puar, J. K. (2012). "I would rather be a cyborg than a goddess": Becoming-intersectional in assemblage theory. PhiloSOPHIA, 2(1), 49-66.

Manning, E. (2016). The minor gesture. Durham, NC: Duke University Press.

Minh-Ha, T.T. (1991). When the moon waxes red: Representation, gender, and cultural politics. New York, NY: Routledge.

Springgay, S., \& Truman, S. E. (2018). Walking methodologies in a more-than-human world: Walkinglab. New York, NY: Routledge. 
Zine, J (2006). Unveiled sentiments: Gendered Islamophobia and experiences of veiling among Muslim girls in a Canadian Islamic school. Equity and Excellence in Education. 39, 239-252.

Wesam M. Salem is a doctoral student in the department of Instruction and Curriculum Leadership at the University of Memphis. Her research interests include mathematics, identity and the intersectionality of race, gender, religion, and national origin in education within postcolonial theory.

Leslee K. Bailey-Tarbett is a doctoral student in the department of Instruction and Curriculum Leadership at the University of Memphis. Her research interests include literacy coaching, professional development, and early literacy education using post-qualitative methodologies, drawing on poststructural and posthumanist perspectives.

Susan Naomi Nordstrom is an associate professor of Educational Research in the Department of Counseling, Educational Psychology and Research at The University of Memphis. She has published about post-qualitative methodologies, and human and nonhuman relationships in post-qualitative methodologies, in leading qualitative research journals.

\footnotetext{
${ }^{i}$ Class members viewed and embodied the three walks differently, while foregrounding the readings of Braidotti (2012), Manning (2016), Haraway (2016), for example. These readings were paired with historical readings on Memphis (i.e. Lauterbach, 2016) and discussions about current Memphis (in particular, the 50th commemoration of Dr. Martin Luther King Jr's assassination) to help students better understand the histories upon which they walked. As students explored these readings, their positionalities (e.g. class, race, gender and religion) factored into how student's conceptualized and blogged about their experiences walking the Memphis neighborhoods. In so doing, students examined what transpires in the neighborhood assemblage event-spaces (Puar, 2012). In order to demonstrate this work, we draw on Puar (2012) to unite the historical readings and feminist readings of the class.

ii Puar's (2012) interrogates the oppositional thinking of intersectionality and the assemblage theory. Instead of thinking of both constructs appositionally, she explores the potentials and limits of thinking of intersectionality in tandem with the assemblage theory.
} 